Messrs. Bosworth \& Co.

Author(s): A. E. Bosworth

Source: The Musical Times, Vol. 55, No. 861 (Nov. 1, 1914), p. 656

Published by: Musical Times Publications Ltd.

Stable URL: http://www.jstor.org/stable/911069

Accessed: 17-06-2016 10:34 UTC

Your use of the JSTOR archive indicates your acceptance of the Terms \& Conditions of Use, available at

http://about.jstor.org/terms

JSTOR is a not-for-profit service that helps scholars, researchers, and students discover, use, and build upon a wide range of content in a trusted digital archive. We use information technology and tools to increase productivity and facilitate new forms of scholarship. For more information about JSTOR, please contact support@jstor.org.

Musical Times Publications Ltd. is collaborating with JSTOR to digitize, preserve and extend access to The Musical Times 
At West Ham Parish Church, on October 4, the service music consisted of the anthem 'In your day of gladness' and other compositions by Mr. G. B. Gilbert, who has completed his thirty-fifth year as organist of the church.

Julius Harrison's 'Harvest Cantata' was given at the Union Chapel, Islington, on October I I, under the direction of Mr. G. H. Betjemann, with Miss Nellie Rose-Innes and Mr. W. Forington as soloists.

Dr. Sinclair gave his hundredth recital at Hereford Cathedral on October I. The proceeds of his recitals are devoted to War Funds, which he has benefited to the extent of $£$ I 20 .

\section{ORGAN RECITALS.}

Mr. C. J. King, Church of St. Matthew, NorthamptonChoral Prelude on 'St. Ann's,' Parry.

Mr. Sydney L. K. Crookes, Kilbarchan U.F. ChurchPrelude and Fugue in G major, Bach.

Mr. Ivor Davies, St. Michael's Church, Manselton, Swansea-Grand Offertoire in D minor, Batiste.

Mr. H. Egbert Lane, St. Stephen's Church, HounslowEpilogue, Healey Willan.

Mr. Albert Orton, Walton Parish Church, LiverpoolAllegro Maestoso from Sonata in G, Elgar.

Mr. Leslie Curnow, Lydiard Street Methodist Church, Ballarat-Concert-Overture in C major, Hollins.

Dr. Keeton, Peterborough Cathedral -Caprice in B major, Bernard Johnson.

Mr. Herbert Hodge, St. Nicholas Cole Abbey-Fugue in E flat, 'St. Ann,' Bach.

Mr. W. H. Seymore, City Hall, Cape Town-Pastorale, Edmondstoune Duncan.

Mr. J. T. Pye, St. Luke's Church, Grimsby-Sonata in D minor, Guilmant (opening of new organ)

Mr. W. H. Maxfield, St. John the Evangelist, AltrinchamOffertoire in $\mathbf{F}$ minor, Batiste.

Mr. J. Patterson Shaw, Northwick Parish Church'Andantino et Chour,' 'ésar Franck.

Mr. J. A. Meale, Wesleyan Central Hall, Westminster'La Sourire,' Bernard Johnson.

Mr. Alban Hamer, All Souls' Church, Leeds-First Sonata, Guilmant.

Mr. C. E. Blyton Dobson, Central Mission, Halifax Place, Nottingham-Sonata in C sharp minor, Harzood.

Dr. G. H. Smith, Sculcoates Parish Church-Andante in G, Wesley.

Mr. Howard Moss, St. George's Church, GravesendPostlude in E flat, Batiste.

Mr. T. S. Guyer, West Keal Parish Church, SpilsbyRhapsodie in D on a Breton melody, Saint-Sä̈ns.

Mr. C. J. King, Church of St. Matthew, NorthamptonLament, Harvey Grace.

Mr. Allan Brown, Regent Square Presbyterian ChurchFugue in G minor (the 'Great'), Bach.

Mr. F. W. Hughes, Horncastle Parish Church-Concert Overture, Hollins.

\section{APPOINTMENTS.}

Mr. Claude A. Forster, organist and choirmaster, St. John's Episcopal Church, Forfar.

Mr. Claude Landi, organist and choirmaster, St. Patrick's, Hove.

Mr. Arthur Mangelsdorff, organist and choirmaster, St. Matthew's, Birmingham.

Mr. Alan H. Thorne, organist and choirmaster, Church of St. Barnabas, Bexhill-on-Sea.

Mr. Sydney H. R. Warnes, organist and choirmaster, St. John's U. F. Church, Largs, Ayrshire.

BOOKS RECEIVED.

The Promenade Ticket. By A. H. Sidgwick. Pp. 207. Price $3 s .6 d$. net. (London : Edward Arnold.)

Pages from an.Unwritten Diary. By S r Charles Villiers Stanford. Pp. 328. Price I2s. 6x. net. (London: Edward Arnold.)

The Children's Corner. Rhymes by R. H. Elkin. Illustrations by $\mathrm{H}$. Willebeek Le Mair. Price $3 s .6 d$. net. (London : Augener, Ltd.)

\section{Correspondence.}

\section{ENGLISH $v$. GERMAN FINGERING.}

TO THE EDITOR OF 'THE MUSICAL TIMES.'

SIR,--It is easy to imagine the jubilance with which Mr. H. C. Tonking's suggestion to re-adopt English fingering in pianoforte music will be received by patriots all over the country. For nearly thirty years our treacherous teachers and editors of music have been doing their wicked utmost to establish a uniformity in fingering, quite regardless of the fact that the sequence of figures 12345 represents a hideously Teutonic aspect of affairs !

Mr. Tonking tells us that publishers would be glad to print English fingering once more, but that is nothing to the radiant gladness that would illuminate the countenances of small music-dealers all over the country at the prospect of selling off their old stocks of 'Popular Classics' and earlyVictorian copies of Beethoven, which have lain on their dusty shelves so long !

May I venture to call attention to another terrible evil in our midst? It is horrible to think that some dastardly teachers of Harmony are still allowing their pupils to write the chord of the German sixth, and may I suggest that some musician as distinguished as Mr. Tonking may come forward to protest against its use in the name of patriotism and National honour?-I am, Yours, etc.,

October 9, 1914

Thomas Dunhill.

TO THE EDITOR OF 'THE MUSICAL TIMES.'

SIR,--The title of Mr. Tonking's letter is a misnomer : there is no such thing as 'German fingering.' There are two methods of indicating the fingering of pianoforte and organ music, one of which is adopted by the leading publishers of England and America and all the publishers of every other civilized nation, while the second method is adhered to by the less-important publishers of .the two countries above-mentioned. Patriotisn has absolutely nothing to do with the matter.

Thoroughly agreeing with Mr. Tonking as to 'the absurdity of having in England two notations for pianoforte fingering,' I would beg to refer him to an article on this subject in the Musical Times for February, 1890 , from the pen of Dr. W. H. Cummings ; an article which, so far as I know, has never been answered, and which appears to me to be unanswerable. - Yours faithfully,

October 3, 1914. Arthur T. Froggatt.

\section{MESSRS. BOSWORTH \& CO.}

TO THE EDITOR OF 'THE MUSICAL TIMES.'

SiR, - I am loth to ask for space on a personal matter, but such a mean, contemptible report is being spread about my firm that I am obliged to do so. It is said, among other things, that 'Bosworth \& Co. have closed up and gone back to Germany.' The inference, of course, is very obvious. I little thought when Sir Arthur Sullivan persuaded me to leave Chappell \& Co., and go to Leipsic, in I 889 to publish his operas, that I should be subjected to a low attack of this kind from my own countrymen in 1914 .

I am sole proprietor of Bosworth \& Co. in the British Empire, and outside the Empire my only partners are my sons, who are as English as I am, and who are both in the British Army-one as an officer at the front, from Mons onwards, and the other a private in 'Kitchener's Army.'Yours truly,

London, October I4, I9I4.

A. E. Bosworth

\section{THE APPOINTMENT OF FOREIGN PROFESSORS AT ABERYSTWYTH.}

TO THE EDITOR OF 'THE MUSICAL TIMES.'

SIR, - In connection with your remarks on the appointment of the five French musicians at the University College of Wales, Aberystwyth, your readers might naturally take the impression that as Professor of Music at the College I had a voice in the selection. I have already received letters 